\title{
How consistent is the new Common Agricultural Policy with the challenges it faces?
}

\author{
Jozsef Popp \\ Professor, University of Debrecen, Hungary \\ E-mail: poppj@ecom.unideb.hu \\ Attila Jambor \\ Assistant Professor, Corvinus University of Budapest, Hungary \\ E-mail: attila.jambor@uni-corvinus.hu
}

\begin{abstract}
The latest reform of the Common Agricultural Policy (CAP) has recently been accepted, identifying important challenges for EU agriculture, but proposing only limited changes to the previous CAP. Now it is time for the implementation of the new measures. However, from a theoretical point of view, it seems that the CAP can hardly meet the challenges it faces due to the inconsistencies between the predefined challenges and the measures proposed to meet them. The aim of the paper is to systematically analyse the consistency between the challenges of European agriculture and the policy measures aimed at meeting them. It seems that not all measures are consistent with the challenges.
\end{abstract}

Keywords: CAP, challenges, measures, consistency

JEL code: Q18

\section{Introduction}

The European Commission (EC) has finalised legislative proposals that set out the overall direction of CAP reform for 2014-2020. The proposals, maintaining some of the fundamental inconsistencies of the current CAP, are presented in a complex economic and political situation. This situation is dominated at present by the Euro sovereign debt crisis, and includes issues such as growing world population, changing lifestyles and diet, price volatility, economic and food crises and global food security, climate change and environmental degradation. It is evident that 
agriculture faces many challenges in the $21^{\text {st }}$ century, especially to increase the production of and access to sufficient and high quality food for a growing world population with changing diet while at the same time massively improving the management and use of scarce natural resources.

To meet these challenges seems to require a radical change in the Common Agricultural Policy (CAP). However, the new reform package largely maintains the status quo and does not resolve the fundamental incoherence, illegitimacy and unsustainability of the CAP. The new measures ignore the facts that Europe is in its biggest crisis since the founding of the European Union and that there are several extremely urgent issues that need to be addressed now to avoid catastrophic problems in the upcoming years regarding food security, climate change and rural development.

The paper provides a conceptual analysis of the challenges European agriculture faces and checks the consistency of these challenges with the latest reform measures. In other words, the aim of the paper is to check whether the new CAP helps European agriculture to meet the challenges it faces or not. The paper is structured as follows. Section 2 shows the challenges and objectives of the CAP and analyses the consistencies between measures and challenges. Section 3 demonstrates some overall dilemmas for the CAP in the future, while Section 4 presents institutional factors determining the playing arena for the future CAP. Section 5 shows a possible road ahead.

\section{Challenges and objectives of the CAP}

The Communication of the European Commission published in 2010 identifies three key challenges for European agriculture (European Commission 2010):

Food security. As the world's population is expected to grow to around nine billion by 2050 , global demand for food will significantly increase, resulting in a measurable growth in world food production. The EU should be able to contribute to world food demand by preserving and improving its agricultural production capacity while meeting the high safety, quality and welfare standards required by its citizens as well. In order to meet this challenge, the CAP has to stabilise incomes and markets as well as improve the international competitiveness of its agricultural 
sector and the functioning of the food supply chain in times of greater market uncertainty, increased price volatility and stagnating agricultural incomes.

Environment and climate change. Agriculture and the environment are inextricably linked. Farming practices can have beneficial (e.g. organic agriculture) or harmful (e.g. intensive agriculture) effects on the environment, while the provision of public goods can potentially offer several environmental benefits (e.g. biodiversity, climate stability, resilience to natural disasters, etc.). At the same time, climate change can have various effects on agriculture in the long run (e.g. flooding, drought, etc.) Therefore, the future CAP should help agriculture mitigate climate change through reduced greenhouse gas (GHG) emissions and various measures to increase production efficiency (e.g. energy efficiency, carbon sequestration, etc.).

Territorial balance. Agriculture is still an important sector in the rural economy, offering job possibilities and income to rural residents and generating many additional economic activities (e.g. food processing, tourism and trade). However, many territorial imbalances, mainly between Old and New Member States, exist in the EU. The CAP should tackle these imbalances by improving the vitality and economic potential of all the rural areas inside the EU.

Three main objectives are derived from these challenges, according to the Communication (European Commission 2010):

Viable food production. In order to reach this objective, the future CAP should (1) contribute to farm incomes and limit their variability, (2) improve the competitiveness of the agricultural sector and enhance its value share in the food chain and (3) compensate for production difficulties in areas with specific natural constraints.

Sustainable management of natural resources and climate action. This objective also contains three elements: (1) enhancing sustainable production practices and securing the provision of environmental public goods, (2) encouraging green growth through innovation and (3) pursuing climate change mitigation and adaptation actions. 
Balanced territorial development. The third objective is also made up of three policy subobjectives: (1) supporting rural employment, (2) improving the rural economy and promoting diversification and (3) encouraging structural diversity in farming systems by improving conditions for small farms and developing local markets.

By thinking in terms of sustainability, the above-mentioned challenges can easily be transformed into economic, environmental and social challenges. In order to meet these challenges, various measures are proposed in the latest CAP reform. It is worth while to analyse whether these proposals are consistent with the challenges - if not, it is doubtful how the former contribute to the latter.

\subsection{Consistency of economic challenges and measures}

The most important economic challenge for the CAP in the future is to secure food supplies. This challenge is to be met via various measures among which probably the most important is the continued provision of direct payments. Established in 1992 and significantly changed in 2003, direct payments are now decoupled from production and pertains to the 'green box' (nondistorting subsidy) of the WTO. Europe spent 70\% of the CAP budget to direct payments in 2012 (European Commission 2013a), aiming to stabilize incomes of farmers. This amount was spent on European farmers representing 5.4 percent of the EU's population and generating 1.6 percent of the Union's GDP (European Commission 2013a).

Despite their obvious importance to European farmer accounts, the vast majority of the professional literature analysing the CAP considers that direct payments are well past their sellby date. Swinnen (2009), for instance, argues that Single Farm Payments (SFP) are not effective in any defensible dimension: (1) Agricultural employment is still decreasing despite large and increasing direct support; (2) the majority of farm household incomes come from off-farm sources, reflecting improved integration of rural areas and markets with the general economy; (3) the distribution of support is very uneven amongst farm sizes (and types and regions), with those perhaps most deserving or needing support receiving the least; (4) most support is dissipated to input suppliers and landowners, since payments are based on historical rights and linked to land 
use; (5) cross compliance is either largely ineffective or impossibly expensive as a means of paying for agriculturally-related public goods (conservation, amenity, recreation and environmental (care) goods and services).

Swinnen (2009) well summarises the arguments that improvements in farm incomes due to support are temporary, which both history and economic logic demonstrate. Competition in the industry soon results in the revenue increase being capitalised in the value of farm assets, or being spent on increased costs of production. In either case, market competition ensures that total production costs will increase to match the supported increase in revenue. In effect, the benefits of support are frozen into higher costs for the sector and its businesses. Entrants to the supported industry have to purchase or rent their farm assets and pay the additional costs generated by the support, and are, consequently, no better off with the policy than they would have been without it. Incomes in the industry continue to be determined largely by the earnings available elsewhere and outside the industry. But, by the same token, removing existing support is especially damaging to new entrants, since many of their expenditures are based on and cannot be justified without the support. Farmers, and thus their industry and political representatives, have become dependent on, if not addicted to continued support.

Moreover, direct payments suffer from very substantial legitimacy problems. They are still calculated on the basis of historical production references and they establish the various levels of support that existed in the past by sector and territory. Furthermore, they do not reflect the changes recorded in the orientations of farms after decoupling as they do not appreciate the flexibility of a farmer in making production decisions. They neither reflect recent changes in market prices, consequently overcompensating producers of cereals and oilseed (direct beneficiaries of the price increases of agricultural commodities), while abandoning livestock producers (who are suffering from an increase in the cost of feedstuffs). Compensation for past price cuts is no longer necessary. Generalised per hectare payments are not targeted, whatever name is given or conditions attached to them (Tangermann 2011).

Meanwhile, there is no evidence that farm households in industrialised OECD countries have systematically lower incomes than other households, so policies to support incomes across the 
whole sector are unjustified (Swinnen 2009). Agricultural income per work unit is not an appropriate indicator of standard of living as it depends on total household income of the family concerned. This means that farm income support has to be based on overall incomes of farm households where income from other sources often complements agricultural income. Direct payments have limited potential for supporting farm income, which is the official motivation of the support. If support was eliminated, land values would fall, structural change speed up and incomes from other sources grow, leaving the total income of farm households (remaining in the sector) more or less unaffected (Sahrbacher et al. 2007). Besides all these, it is pretty hard to understand why the CAP subsidises farmers' incomes in times of increasing food prices. As evident from Figure 1, producer prices have increased for almost all countries and products concerned in the European Union from 2004-2006 to 2011. Cereals prices have experienced the biggest increase, followed by meat and milk prices. As price increases have reached $100 \%$ in many cases, direct payments contributing further to farmers' incomes seem obsolete.

Figure 1. Producer price indices for selected products in the EU27 in 2011 (2004-2006=100, \%)

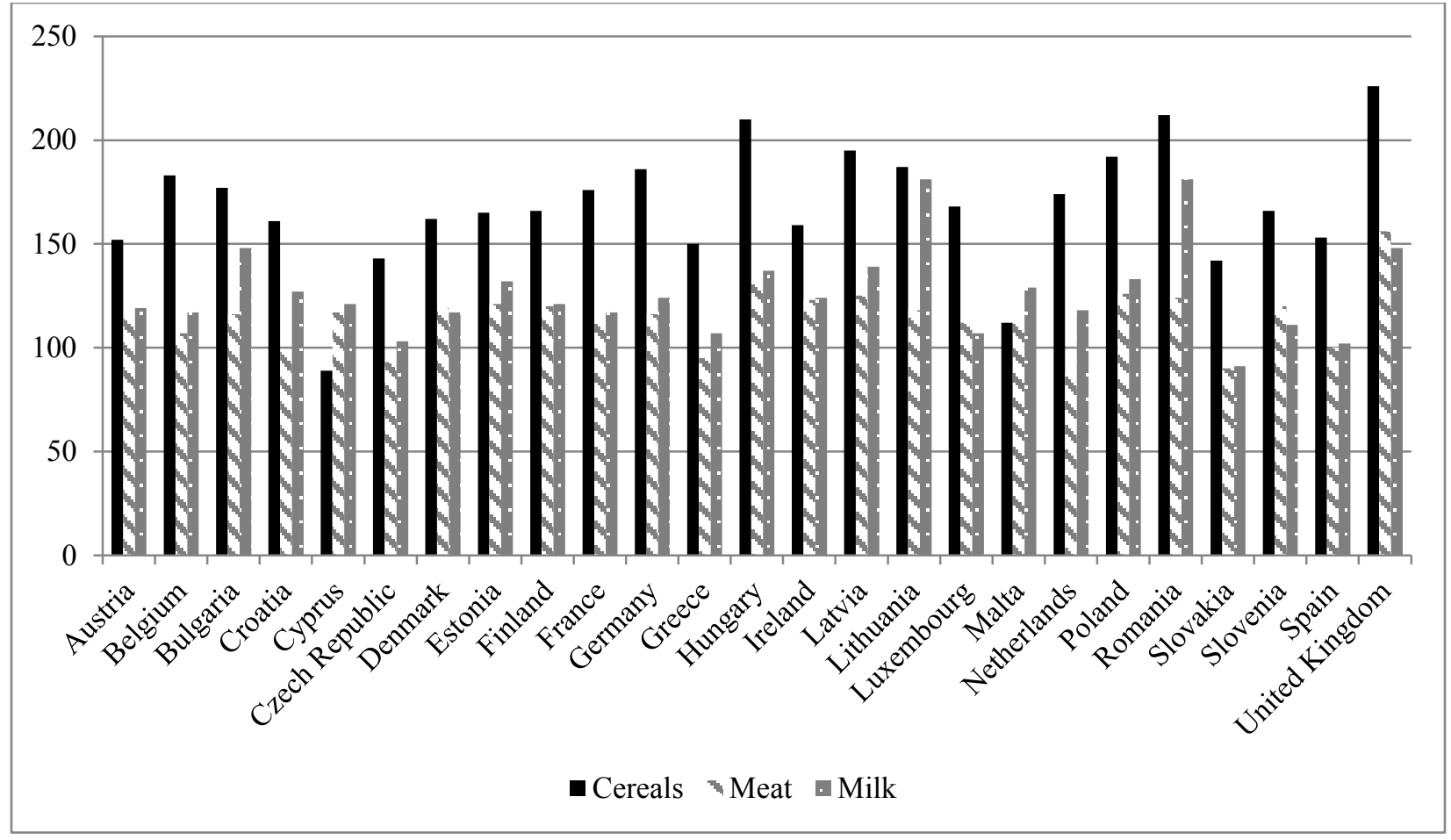

Source: composed by the authors based on FAO (2014) 
Direct payments are neither equitably distributed by farm size, nor by geographical location (EC, 2013a). The 80/20 rule applies - approximately 80 per cent of the support goes to 20 per cent of farmers (recipients). Small farmers, especially, are handicapped in many ways. Though they are eligible for direct payments, due to the small farm size and administrative procedures, most receive marginal amounts or do not even participate in the system. As Zahrnt (2009) and others have also emphasised, payment rates per hectare are also widely dissimilar, ranging from $€ 500+$ in Greece to $€ 174$ in Portugal. Furthermore, following the EU Copenhagen agreement, direct payments were introduced at lower initial rates in the new Member States (NMS), which have still not reached the level of the EU15 in Romania, Bulgaria and Croatia. However, the EU10 reached the 100 per cent payment level in 2013. Indeed, the NMS complemented for the transitional period of 10 years EU-funded direct payments with national supplements to make good the difference between their own payment rates and those of the old (and largely richer) Member States.

The common status of these payments has been violated and national co-funding has been established. A little-remarked consequence is that the budgetary cost to the EU of the SFP rose significantly from the level of EU accession (25 per cent) to 2013 as the EU-funded component of the SFP rose to 100 per cent in the EU10, while pressures to reduce the budgetary cost of the policy also rose.

Moreover, there is a critical paradox at the heart of the claim that SFPs are WTO green: if, indeed, SFPs do not distort farm production decisions, what exactly, do they do? If these payments help farmers at all, they must result in farms staying in business when they otherwise would not, and therefore cannot help but affect the structure of production. Whether or not this structural effect also and necessarily affects the total European volume of production, and if so, in what direction, remains an empirical question. It may be possible to defend claims for green box status for the SFP system, though this is not guaranteed. In any event, world trading partners can be expected to continue to seek ways of challenging the green status of SFPs so long as the inherent paradox remains. 
Based on these critiques, the 2013 CAP reform changed the former system of direct payments and introduced various novelties (e.g. greening, small farmers scheme, internal and external convergence, active farmers, etc.). However, it seems that even the modified system of direct payments is not consistent with the challenge of increased food security.

First, as the current system of decoupled direct support suggests, a farmer need not even produce to receive a fixed income. If a farmer does not produce agricultural commodities, it is hard to imagine how he or she contributes towards ensuring global food security. Consequently, stabilising farmers' incomes does not necessarily mean guaranteeing food security, despite the fact that food security still remains the Commission's major reason for maintaining farm income support. By seeking to stabilise all farmers' incomes, current direct payments seem to focus on social and environmental issues instead of focusing on enhancing the competitiveness of farms. Second, greening is also against food security - by introducing super-cross-compliance type measures (Matthews 2011), competitiveness and profitability of farmers are decreasing. In addititon, greening is a high-cost policy compared to payments directly targeting public goods. Moreover, many farmers treat ecological focus areas as a resurrection of set-aside abolished in 2008, while diversification of crops is fully against economies of scale (Matthews 2011). Third, the maintenance of coupled subsidies might help reaching food security in specific regions, though the magnitude of its impact is doubtful. Fourth, specific programmes for small scale farmers, on the one hand, decrease administrative costs of small farms, though on the other hand, it does not encourage creating efficient scales and support keeping the land price high. Fifth, redistribution of direct payments helps decreasing inequalities, though its extent is dubious.

On the whole, it is evident that problems raised above are treated by the new system of direct payments but not solved. It is an interesting question whether direct payments will exist even after 2020.

Besides direct payments, according to the European Commission (2010), food security should be reached via the stabilization of agricultural markets. It is a serious concern for the future whether the CAP can really stabilize agricultural markets. The economic and food crisis of 2008 and 2011 highlighted that the issue of food security, which seemed to have been already solved since the 
1970s, is now back to the policy agenda. Extreme price volatility, experienced in global markets since 2008, has serious consequences for the stabilisation of agricultural markets. Furthermore, it seems that food prices will remain at a generally higher level in the future.

In addition to the stabilization of farm incomes, the European Commission seeks to increase competitiveness of European agriculture, thereby meeting the challenge of global food security. However, the way of doing so also has some caveats. First of all, competitiveness enhancement of agriculture pertains to the second pillar of the CAP, though some elements (market stabilization, direct payments, etc.) will remain in the first pillar. It is a question, therefore, what coherence would exist between the two pillars to target this issue.

Enhancing competitiveness has implications for trade policy. EU agriculture as a whole is required to compete in the world market, and trade policy basically determines the way it does so. In order to enhance the competitiveness of its farmers, the EU has many trade policy tools, from increasing import tariffs to banning imports of specific agricultural products coming from outside the Community, but these options are not respected by the WTO. Competitiveness can also be strengthened by further increasing subsidies to farmers, thereby reducing their already high costs of production, though this again may not be the best solution in the long run because subsidies artificially shield farmers from healthy competition hindering the evolution of more modern, more efficient agriculture. Direct payments may allow farmers to withstand international competition. However, such "artificial" competitiveness keeps agriculture dependent on government payments.

Increasing European food safety standards are also against the competitiveness of EU agriculture. Cross-compliance, greening requirements as well as plant and animal welfare measures imply additional costs for European farmers compared to their third country counterparts. Therefore, it is dubious how the CAP, based on high standards, will increase competitiveness in the long run as Europe faces increasing competition in the globalised agricultural and food system. However, food is more than just a commodity. European consumers demand healthy and safe food and thus the major challenge for European farmers is to make their 
products visible and recognisable to all European consumers for its quality, safety and diversity and thereby making them different to products coming from outside the EU.

Moreover, issues related to genetically modified organisms (GMOs) are also on the table when talking about agricultural competitiveness in Europe. Do GMOs have a European future, or will they continue to be marginalized by many European consumers and governments? And if so, will this be accepted by the EU's major trading partners, or will it lead to trade conflicts and new disputes in the World Trade Organization (WTO)? As the share of genetically modified products is increasing in world trade, agricultural competitiveness is largely determined by the decision on their use.

On the whole, one must take into account that there is no study describing and testing scenarios under which EU food supplies would be insufficient (Zahrnt 2011). However, without evidence, it is unclear how a major policy instrument of the CAP can be justified.

\subsection{Consistency of environmental challenges and measures}

The CAP is faced with numerous environmental challenges, including, inter alia, GHG emissions and climate change, soil depletion, water/air quality, habitats and biodiversity. These challenges are best tackled by focusing on the sustainable management of natural resources and climate action with three-sub-objectives: sustainable production practices and the provision of environmental public goods, green growth through innovation and climate change mitigation and adaptation actions (European Commission 2010). The long run sustainability of agriculture in the EU depends on maintaining the underlying natural resource (soil, water, air and biodiversity) base. Although farmers are the managers of the majority of land and water resources across the EU, agriculture provides a modest or even declining share of economic activity in most rural areas (Cunha - Swinbank 2011). In practice, the latest CAP reform elaborates greening measures, while green growth and climate change mitigation and adaptation actions seem to remain high-flown rhetoric. 
In the current system, cross-compliance represents the compulsary basic layer of environmental requirements and obligations to be met in order to receive full CAP funding. On top of this, from 2015 onwards, the CAP introduces green direct payment rewarding farmers for respecting three obligatory agricultural practices, namely maintenance of permanent grassland, ecological focus areas and crop diversification. At least $30 \%$ of the budget of each rural development programme must be reserved for voluntary measures that are beneficial for the environment and climate change (agri-environmental- climate measures, organic farming, areas for natural constraints, Natura 2000 areas, forestry measueres, and investments which are beneficial for the environmnet or climate). However, greening measures still have many deficiencies.

First, linking direct payments to the provision of public goods is an illogical conception. Since 1992, direct payments have been given for many reasons but it is clear that the system is still based on the reference yields of 1986-1990 (2000-2002 for the new members). Thereby the new conception implicitly assumes that those receiving a high amount of direct payments (e.g. those who had high yields in the reference period) provide numerous public goods, which is surely not the case. In marginal regions where costs of production are high, direct payments can contribute to more biodiversity and landscape preservation (Brady et al. 2009), though these payments are the highest in fertile regions due to their origin as compensation for price cuts. As evident from Figure 2, there is no clear relationship between direct payments and NATURA 2000 areas (as a proxy for measuring agri-environmental status). We can not state that those regions with higher environmental values get more direct payments. Actually, correlation between the two indicators is negative at the EU27 level $(\mathrm{R}=-0.29)$ (European Commission 2013a).

Figure 2. Relatonship between direct payments and NATURA 2000 areas in EU27 in 2012 


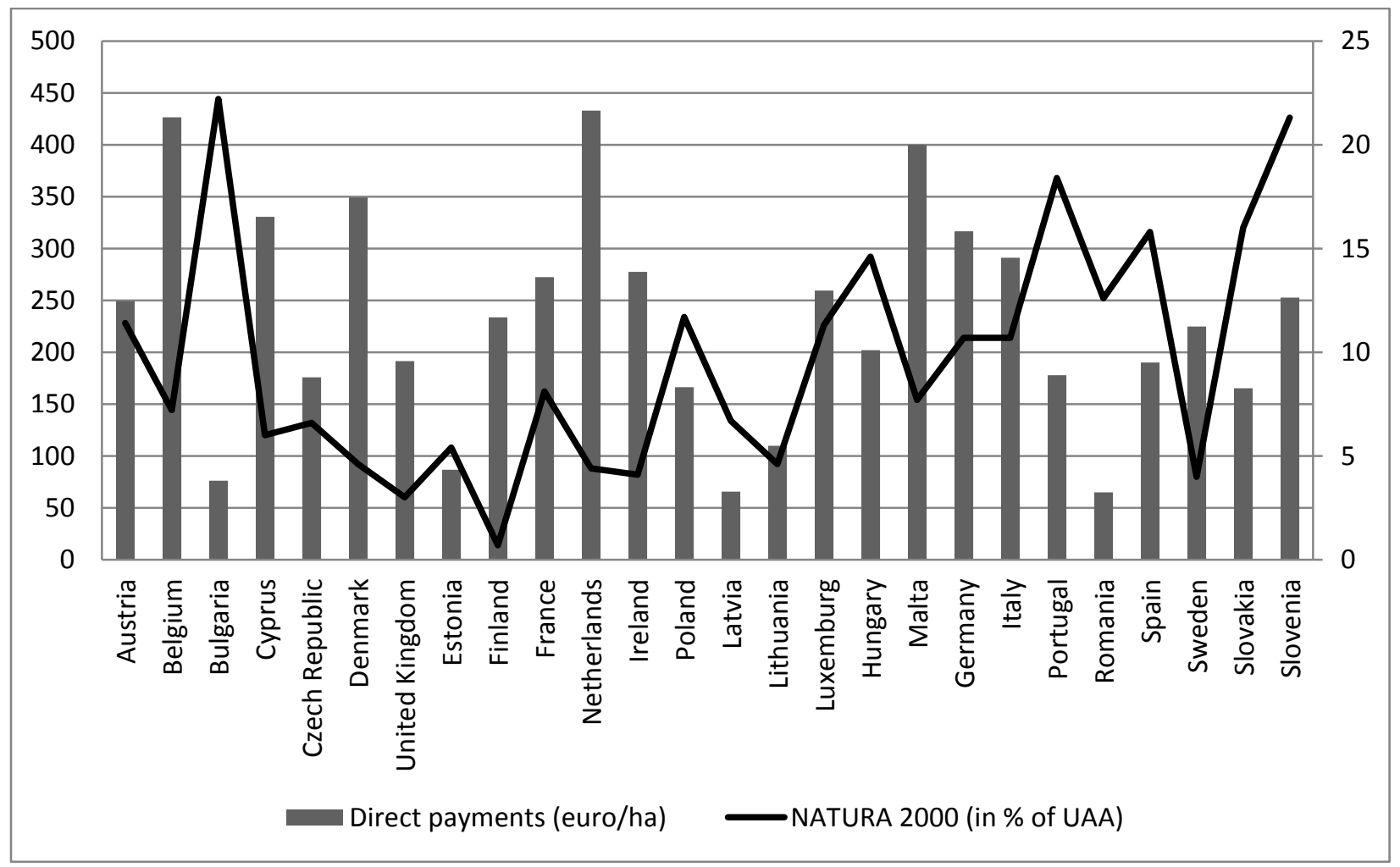

Note: Direct payments are calculated per hectare (based on UAA data).

Source: composed by the authors based on European Commission (2013a)

Second, the Communication seems to neglect the fact that one of the biggest problems with the provision of environmental public goods in agriculture lies in the insufficiency of measurement methods. If we are to achieve global objectives for halting/slowing down biodiversity loss, it is important that we demonstrate the economic value of ecosystem goods and services. However, we cannot measure - aside from making educated guesses - the value of a landscape or the value of biodiversity, and it is unclear what kind of methods the Commission proposes for solving this problem. Over the past decade, progress has been made in understanding how ecosystems provide services and how service provision translates into economic value. Yet, it has proven difficult to move from general pronouncements about the tremendous benefits nature provides to people to credible, quantitative estimates of ecosystem service values. Spatially explicit values of services across landscapes that might inform land-use and management decisions are still lacking (Balmford et al. 2002; Reid et al. 2005). 
It is also questionable as to whether we have a common value for public goods for Europe and it is very doubtful that the same public goods policy should apply to Old and New Member States, still less for each and every region or farm. Moreover, without knowing the proper indicators and measurement methodology, the efficiency of the delivery of environmental public goods can hardly be evident. Questions arise as to who will evaluate (and on what basis) whether public money spent on the provision of public goods has lead to the achievement of the policy's aims or not. Going further, if we can not measure the outcome, or Member States are not willing to pay for it from the national budget, it is doubtful that taxpayers will understand exactly what they are paying for.

Third, the CAP seems to do little to meet the EU's overall objective in its Biodiversity Strategy for 2020 - to halt the loss of diversity and to restore degraded ecosystems. Ecological Focus Areas (EFAs) are limited to less than $50 \%$ of the EU arable area and permanent crops, grasslands or pastures do not need EFA. EFAs can also include land uses with doubtful benefits for biodiversity. In the absence of specific management guidelines, EFAs will likely contribute little to biodiversity. Cultivating three crops on large, intensively managed farms is unlikely to enhance biodiversity and these targets are currently lower than existing average crop diversity in many member states. In addition, the new regulation did not do more to improve the costeffectiveness of Pillar 2 schemes in terms of uptake and biodiversity outcomes (Pe'er et al. 2014).

Fourth, the provision of public goods seems to require significant institutional and administrative background for the management of these programmes. It is doubtful that these programmes can be well-administered without a measurable increase in bureaucracy both at the EU and national level. However, such an increase would result in cost increases and work against the "cutting the red tape" principle, as indicated by the Commission (European Commission 2010).

Fifth, the coherence between greening and the current agri-environmental programmes remains questionable. The question is what the greening component could potentially deliver that cannot yet be delivered by the existing instruments. It is not clear why the respective set of agrienvironmental actions should be moved from the second pillar to the first pillar with its much different implications for decision making and financing. As the payments under the greening 
component will be financed out of the EU budget, without any national co-financing, member states will feel to make sure the money from Brussels provides the highest conceivable benefits. So the choice of actions chosen from the menu for implementation of the greening component in the individual member states is not primarily based on the most needed and effective agrienvironmental policy but on what promises the largest benefits to domestic farmers (Tangermann, 2011).

Sixth, it is not clear whether subsidies from the first pillar are more efficient than those from the second. As the principle of equivalence, developed by the latest CAP reform, suggests, farmers participating in specific agri-environmental programmes (organic production, Natura 2000 etc.) automatically meet greening requirements, implying that second pillar instruments are better serving the environment than first pillar ones. However, the first time in the history of the CAP, the share of first pillar funds are increasing at the expense of the second. Based on these problems, another logical question arises as to what effect the "greening component" would have on the expenditure balance between the two pillars.

Innovation, green growth and climate change mitigation are also important objectives of the CAP, though the 2013 CAP reform have not elaborated measures in this regard. We are not aware of the exact places and the magnitude of impacts of climate change, for instance, nor is it clear how the CAP would tackle the obvious challenges in this regard. Although the fifth priority of the second pillar is related to climate change, objectives are overly general without details.

\subsection{Consistency of social challenges and measures}

The objective of balanced territorial development is planned to be tackled by supporting rural employment, improving the rural economy and promoting diversification and encouraging structural diversity in farming systems by improving conditions for small farms and developing local markets. Measures elaborated for reaching these aims are the Common Strategic Framework, the new rural development priorities, the simplification of rural development subsidies, the introduction of minimum spending requirements (agri-environment 30\%, Leader (or CLLD) 5\%) and the introduction of European Innovation Partnerships. 
Although these measures bring new concepts to the European rural development policy, several concerns emerge regarding their effectiveness. First and foremost, it is still not clear what rural development is about in the CAP. On the basis of the former four axes, the current six priorities and their associated funding, rural development is mainly about agricultural competitiveness enhancement and agri-enviornmental support, while classical rural development seems to be sidetracked. Increasing quality of life, creating jobs, alleviating rural poverty, decreasing the urbanrural income gap or developing rural infrasturcutre remain just objectives in slogan without any clear measures for reaching them. This argument is also strengthened by the fact that around $20 \%$ of the CAP budget is spent on rural development, while $20 \%$ of the rural development budget is spent on classical rural development - all this ends up in $4 \%$ of the CAP is spent on core rural development issues. As Figure 3 suggests, that vast majority of rural development funds were spent on the first two axes in the EU in 2007-2013, while classical rural development played just a marginal role in most member states.

Figure 3. Relative importance of the 3 thematic axes by Member State (2007-2013)

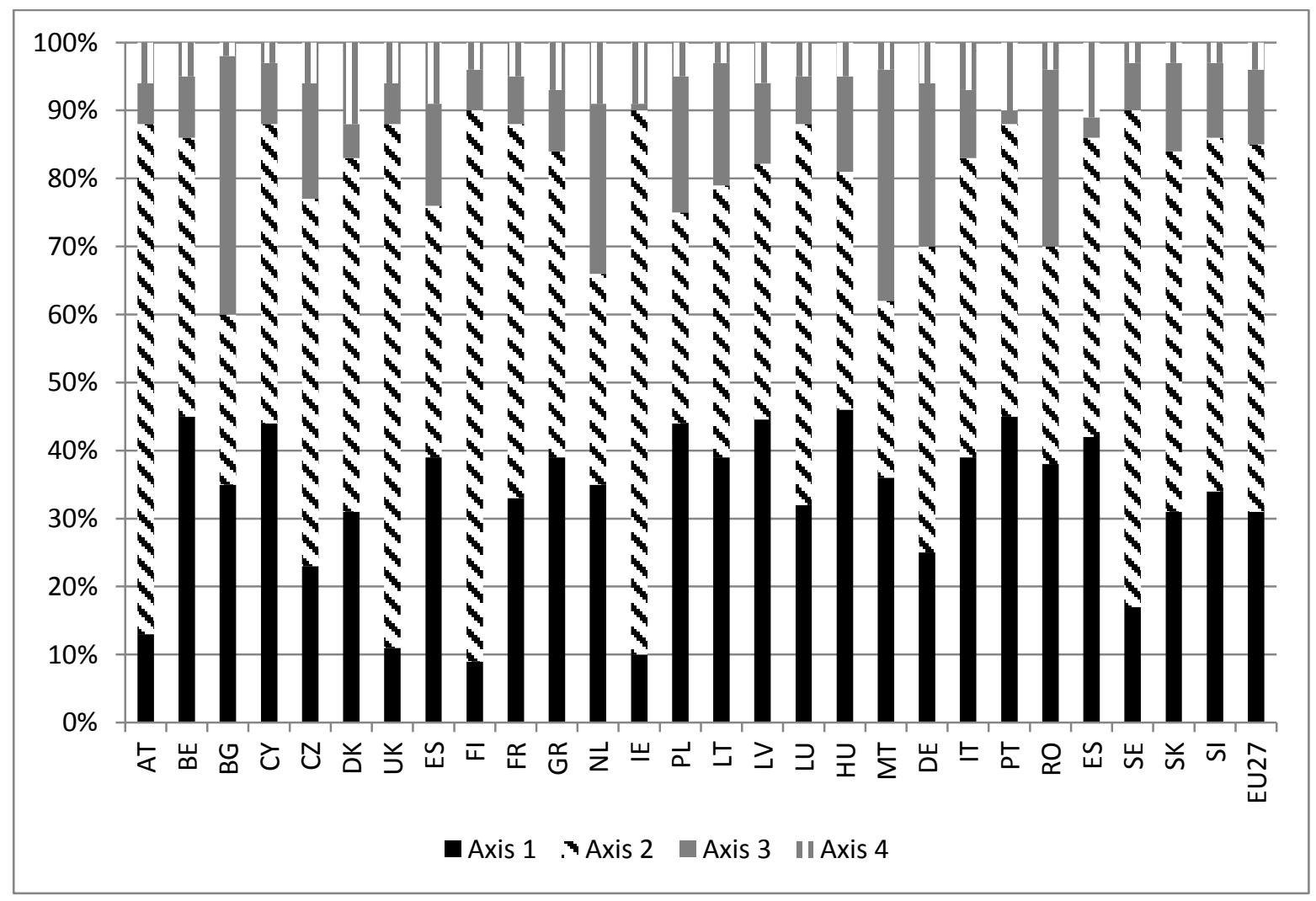


Source: composed by the authors, based on European Commission (2013a: 303).

The exact place of rural development within the EU policy framework is also unclear. On the one hand, the CAP has recently expanded its traditional agricultural focus to a broader array of rural actors via Axis 3 and 4 (territorial approach, though many measures of the other axes (sectoral approach) also have a number of second order effects (enhancing local agricultural employment, tourism, etc.), retaining people in rural areas. This process strengthens the retention of rural development policy inside the CAP together with the fear that cohesion policy would be more likely to focus on urban centres rather than rural areas. On the other hand, there are also strong grounds for arguing that rural development should be reallocated into the Cohesion Fund. One of the strongest arguments, put forth by DG Regio, is that such a shift would bring increased coherence in rural development at the EU level.

Coordination of the various EU Funds seems to have caused difficulties for many Member States concerning their management, thereby causing the lack of synergies and a number of overlaps between them. Given the birth of the Common Strategic Framwork, it seems that rural development will still be funded by the CAP, though the effectiveness of rural development programs is a key question for the future.

Table 1 summarises the arguments made in this section.

Table 1. Challenges, objectives and measures of the CAP 2014-2020

\begin{tabular}{|c|c|c|}
\hline Challenges & Objectives & Measures \\
\hline Food security & $\begin{array}{l}\text { 1. Farm income support and } \\
\text { limitation of variability } \\
\text { 2. Competitiveness and value } \\
\text { share enhancement of agricultural } \\
\text { sector } \\
\text { 3. Compensation in areas with } \\
\text { specific natural constraints }\end{array}$ & $\begin{array}{l}\text { 1. Direct payments } \\
\text { 2. Stabilisation of agricultural markets } \\
\text { 3. Competitiveness enhancement }\end{array}$ \\
\hline $\begin{array}{c}\text { Environment and climate } \\
\text { change }\end{array}$ & $\begin{array}{l}\text { 1. Sustainable production } \\
\text { practices and the provision of } \\
\text { environmental public goods } \\
\text { 2. Green growth through } \\
\text { innovation } \\
\text { 3. Climate change mitigation and } \\
\text { adaptation actions }\end{array}$ & $\begin{array}{l}\text { 1. Enhance the provision of public goods via } \\
\text { the greening component of direct payments } \\
\text { 2. Promote green growth through innovation } \\
\text { 3. Pursue climate change mitigation actions }\end{array}$ \\
\hline Territorial balance & 1. Support for rural employment & 1. Support rural employment \\
\hline
\end{tabular}




\begin{tabular}{|c|c|c|}
\hline & $\begin{array}{c}\text { 2. Enhance and diversify the rural } \\
\text { economy }\end{array}$ & $\begin{array}{c}\text { 2. Improve the rural economy and promote } \\
\text { diversification }\end{array}$ \\
$\begin{array}{c}\text { 3. Improve conditions for small } \\
\text { farms and develop local markets }\end{array}$ & $\begin{array}{c}\text { 3. Allow for structural diversity in farming } \\
\text { systems }\end{array}$ \\
\hline
\end{tabular}

Source: composed by the authors

\section{Overall dilemmas}

Regarding the future of the CAP, several general dilemmas emerge, having impacts on economic, environmental and social measures. First of all, it is questionable to what extent national agricultural policies will increase their role inside the CAP. Several signs of the latest reform indicate that member states get more freedom in the implementation of the CAP (distribution of the different components of direct payments, defining national rural development priorities, etc.) This is an important issue as different national implementations might alter the overall consistency between challenges and measures.

The second dilemma is raised in connection with the structure of the two pillars. Although the first pillar has traditionally dealt with agricultural markets (and direct payments later on) and the second with rural development, many measures are questioning this divison of tasks (e.g. greening in the first pillar, payments for young farmers and LFA from both pillars, competitiveness enhancement from the second pillar, etc.). A consistent CAP would require a clear division of work. Maintaining two pillars, one requiring co-financing and the other not, will also maintain the bias against rural development payments, which need to be matched with domestic funds. The convergence of payments across member states is generally more the product of considerations of what might be politically acceptable than of an economic logic.

Last but not least, it is still questionable whether the 'one size fits all' approach is working for the CAP. Can we apply the same policy for different regions? The current CAP has been planned for meeting the needs of the founders and old member states, though needs of the new members are hardly touched upon (Gorton et al. 2009). This issue might also alter the CAP's capacity to meet the challenges European agriculture faces, especially considering possible new accession rounds. 


\section{The role of institutional factors}

Various institutional factors will also determine whether European agriculture will meet the challenges it faces. In designing the CAP, factors outside agriculture should also be taken into account.

The first institutional factor is EU's overall development strategies (currently the Europe 2020), determining the playing arena for the CAP. European agriculture can contribute to the five priorities defined by Europe 2020 in many ways. On the one hand, the promotion of renewable energies and the support for agri-environmental programmes will help decreasing the emission of greenhouse gases. On the other hand, supporting the local economy and job creation might help increasing rural employment and alleviating rural poverty. Furthermore, the promotion of research and development in agriculture also help innovation.

The second important institutional factor is the budget of the European Union. The substantial pressures on the EU budget indicate that traditional agricultural support is not likely to be preserved at anything like its present level in the future. At present, Pillar 1 of the CAP continues to be wholly financed by the EU budget, in contrast to all other European policies. This 'financial solidarity' provision is a relic of the old market intervention CAP, and is not strictly necessary for a CAP dominated by decoupled single payments. Any decisions on the budget will have an impact on how effectively European agriculture can meet the challenges it faces.

The third institutional factor is the WTO and the international trade talks which have always been and will continue to be a major external pressure on the shape and form of the CAP. Present calls from some quarters for a return to market intervention are inconsistent with present WTO rules, to say nothing of the revised rules likely to be agreed sometime under Doha. The CAP is presently 'WTO-compliant' - in that the SFPs, particularly, can be included in the 'green' (nondistorting) box, exempting them from either control or dispute through the WTO. So long as this is the case, further negotiated reductions in import tariffs, and elimination of export subsidies may well generate strong pressure within the EU for extension, even increases, in SFPs in 
compensation for the reduced market support, as has happened to date. As the EU28 became the world's number one exporter of agricultural and food products in 2013, the role of WTO trade negotiations even increases (European Commission 2014). However, EU farm producer prices are now very close to world market prices, suggesting that high tariffs are largely redundant in providing protection to EU producers. Yet, they still prevent third countries from competing on the EU market (WTO 2013).

Last but not least, global agreements of the EU with third countries also play a role in the effectiveness of the agricultural policy in Europe. The slow progress of the Doha Development Agenda contributed to the intensification of regional trade agreements (e.g. with Asia and Korea). As the US is currently about to offer preferential market access to its South-East Asian trade partners, the EU is under pressure to lose existing trade partners from the region (European Commission 2013b). Moreover, the currently running trade talks between EU and US on free trade can bring significant economic gains as a whole for the EU (Francois et al. 2013). On the whole, if the EU signs new agreements with third countries, these might have agricultural consequences (like the free trade agreement signed with Canada). This factor also contains possible further enlargements of the EU, implying new measures for the current system consisting of 28 member states.

\section{The road ahead}

Based on the arguments above, it seems that European agriculture will hardly meet the challenges it faces as there exists just a partial consistence between agricultural challenges and measures. It is very doubtful how the could CAP meet the challenges it faces. We believe that fundamental challenges are needed in the future, addressing the key challenges as follows:

1. Build the CAP on three pillars. As evident from above, two pillars for three challenges are not enough. Instead, all challenges should be associated with their own pillar, thus creating a food, an environmental sustainability and a territorial balance pillar. Such a system would be more transparent and better focused as well as it would create a better division of tasks among pillars. 
2. Phase out the system of direct payments. It is evident that direct payments are well past their sell-by-date. They are not effective in making European agriculture more food secure nor are they capable of making efficient contributions to the provision of public goods. Better targeted policy instruments are needed to make European agriculture food secure and competitive. Innovation based on research and development, education and training, advisory services and appropriate institutions serving agriculture are the major means of raising productivity, thus enhancing competitiveness. From the food security side, there is no need to make direct payments in order to stimulate extra production in Europe. In response to the challenge of global food security, more food production in Europe cannot make a contribution to that goal as it would make it more difficult for developing country agriculture to create income and employment opportunities (Tangermann 2011). Europe has to concentrate on competitiveness and productivity.

3. Invest in climate smart agriculture. Greening, as we suggest, is not an efficient policy instrument in meeting the environmental challenges European agriculture faces. The future CAP should focus on adapting European agriculture to climate change by heavily investing in research and technology. Conducting research and developing tools for quantifying environmental impacts of farming practices is of great importance as well. A proper monitoring and evalutation system should be created for measuring environmental impacts on the farm level and giving feedbacks to policy makers on the efficiency of environmental instruments.

4. Create a real rural development policy. The future CAP should clean rural development policy by focusing solely on classical issues of rural development like poverty reduction, job creation and investment in rural infrastructures with the overall aim of increasing rural quality of life. It is a reasonable objective for a common policy for agriculture to contribute to reduction of poverty and cohesion. All other activities (competitiveness, agri-environmental issues) should be placed in the other pillars

\section{Conclusions}

The paper has analysed the challenges European agriculture faces and has checked for the consistency of these challenges with the latest reform measures. We found that economic, 
environmental and social challenges, identified by the Commission, do not seem to align with the measures proposed to meet them. Direct payments along with the EU's agricultural competitiveness and food quality policies do not help in reaching the food security goal, while greening measures can hardly contribute to the environmental challenges European agriculture faces. Moreover, the EU's rural development policy is ineffective in meeting the well known European social challenges. A new three pillar CAP, with phased-out direct payments, focusing on climate smart agriculture and genuine rural development policy, along the lines we suggest, is the key for the future.

\section{References}

Balmford, A. - Bruner, A. - Cooper, P. - Costanza, R. - Farber, S. - Green, R.E. - Jenkin, M. Jefferiss, P. - Jessamy, V. - Madden, J. - Munro, K. - Myers, N. - Naeem, S. - Paavola, J. Rayment, M. - Rosendo, S. - Roughgarden, J. - Trumper, K. - Turner, R.K. (2002): Economic reasons for conserving wild nature. Science 297(5583): 950-953.

Brady, M. - Kellermann, K. - Sahrbacher, C. - Jelinek, L. (2009): Impacts of Decoupled Agricultural Support on Farm Structure, Biodiversity and Landscape Mosaic: Some EU Results. Journal of Agricultural Economics 60(3): 563-585.

Cunha A. - Swinbank, A. (2011): An Inside View of the CAP Reform Process, Explaining the MacSharry, Agenda 2000, and Fischler Reforms. Oxford: Oxford Scholarship Online.

European Commission (2010): The CAP towards 2020: Meeting the food, natural resources and territorial challenges of the future. COM (2010) 672 final.

European Commission (2013a): Report on the distribution of direct aids to agricultural producers (financial year 2012). Ref. Ares(2014)3550152 - 27/10/2014

European Commission (2013b): Commission staff working document: Impact Assessment Report on the future of EU-US trade relations. SWD(2013) 68 final.

European Commission (2014): Monitoring Agri-trade Policy: Agricultural trade in 2013: EU gains in commodity exports. MAP 2014-1.

FAO (2014): FAO Statistics. http://faostat3.fao.org/faostat-gateway/go/to/home/E, accessed 1 April 2015. 
Francois, J. - Manchin, M. - Norberg, H. - Pindyuk, O. - Tomberger P. (2013): Reducing Transatlantic Barriers to Trade and Investment: An economic assessment. London: Centre for Economic Policy Research.

Gorton, M. - Hubbard, C. - Hubbard, L. (2009): The folly of the European Union Policy Transfer: Why the Common Agricultural Policy (CAP) does not fit Central and Eastern Europe? Regional Studies 43(10): 1305-1317.

Matthews, A. (2011): Post-2013 EU Common Agricultural Policy, Trade and Development. A Review of Legislative Proposals. ICTSD Programme on Agricultural Trade and Sustainable Development, Issue Paper No. 39.

Pe'er, G. - Dicks, L.V. - Visconti, P. - Arlettaz, R. - Báldi, A. - Benton, T.G. - Collins, S. Dieterich, M. - Gregory, R. D. - Hartig, F. - Henle, K. - Hobson, P.R. - Kleijn, D. Neumann, R.K. - Robijns, T. - Schmidt, J. - Shwartz, A. - Sutherland, W.J. - Turbé, A. Wulf, F. - Scott, A.V. (2014): EU agricultural reform fails on biodiversity. Agriculture Policy Science 344(6188): 1090-1092

Reid, W.V. - Mooney, H. - Cropper, A. - Capistrano, D. - Carpenter, S.R. - Chopra, K. Dasgupta, P. - Dietz, T. - Kumar D.A. - Hassan, R. - Kasperson, R. - Leemans, R. - May, R.M. - McMichael, T. - Pingali, P. - Samper, C. - Scholes, R. - Watson, R.T. - Zakri, A.H. Shidong, Z. - Ash, J. - Neville, B.E. - Kumar, P. - Lee, M.J. - Raudsepp-Hearne C. Simons, H. - Thonell, J. - Zurek, M.B. (2005): Millennium Ecosystem Assessment: Ecosystems and human well-being - biodiversity synthesis. Washington D.C.: World Resources Institute.

Sahrbacher, C. - Schnicke, H. - Kellermann, K. - Happe, K. - Brady, M. (2007): Impacts of Decoupling Policies in Selected Regions of Europe, IDEMA Deliverable 23.

Swinnen, Johan F.M. (2009): On the Future of Direct Payments. Paper presented at the BEPA Workshop. February 26, 2009.

Tangermann, S. (2011): Direct payments in the CAP post 2013. Brusseld: European Parliament. Zahrnt, V. (2011): Food Security and the EU's Common Agricultural Policy: Facts Against Fears. ECIPE Working Paper No. 01/2011.

Zahrnt, V. (2009): Public Money for Public Goods: Winners and Losers from CAP Reform. ECIPE Working Paper No. 08/2009.

WTO (2013): Trade Policy Review: European Union. Geneva: World Trade Organization. 